\title{
Choroidal metastasis as the sole initial presentation of small cell lung cancer
}

\author{
Albert John Bromeo (ㄱ) , Patricia Grulla-Quilendrino, ${ }^{1}$ Sweet Jorlene Lerit, ${ }^{1}$ \\ Gary John Mercado ${ }^{2,3}$
}

${ }^{1}$ Asian Eye Institute, Makati, Philippines

${ }^{2}$ The Medical City, Pasig, Philippines

${ }^{3}$ University of the Philippines Manila, Manila, Philippines

\section{Correspondence to}

Dr Albert John Bromeo; albert.bromeo@gmail.com

Accepted 11 December 2020

\section{DESCRIPTION}

A 62-year-old Filipino woman came in for a primary symptom of insidious-onset blurring of vision on the right eye. The medical history revealed hypertension but no other comorbid illnesses. There were no other problems on review of systems.

Eye examination revealed a best corrected visual acuity of 20/30-2 (manifest refraction of +2.00 sphere -0.50 cylinder $\times 135)$ on the right eye and 20/20 (manifest refraction of +0.50 sphere -0.50 cylinder $\times 95)$ on the left eye. Anterior segment examination revealed nuclear sclerosis on both eyes but was otherwise unremarkable. Dilated fundus examination revealed two irregularly shaped hypopigmented elevated choroidal masses on right eye (figure $1 \mathrm{~A}$ ), with the larger mass measuring around $9.5 \times 12 \mathrm{~mm}$ and just encroaching on the inferotemporal aspect of the fovea. There were similar smaller hypopigmented choroidal masses on the left eye (figure 1B). Multimodal imaging was done to characterise the choroidal masses. Fluorescein angiography (figure $2 \mathrm{~A}$ ) revealed that the mass on the right eye showed hypofluorescence in early phases with increasing hyperfluorescence in a staining pattern in later phases. The mass on the left eye exhibits a weak pattern of staining in later phases (figure 2B). Optical coherence tomography showed choroidal elevations with associated subretinal fluid on both eyes (figure 2C,D). Ocular ultrasound (figure $2 \mathrm{E}, \mathrm{F}$ ) localised the masses to
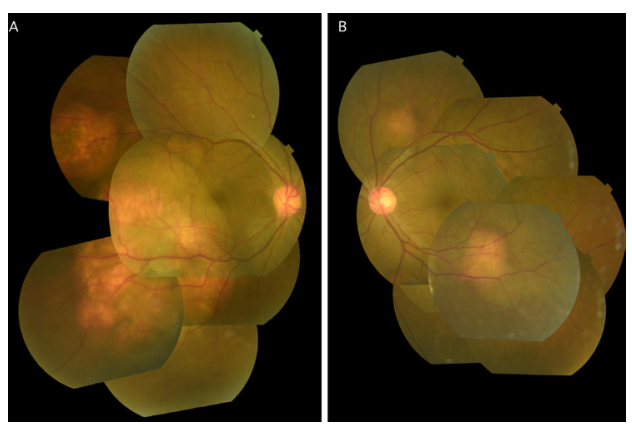

Figure 1 Montage colour fundus photographs. In the right eye $(A)$, there are two subretinal masses-a $3.0 \times 3.2 \mathrm{~mm}$ mass at the end of the superotemporal arcade, and a larger $9.5 \times 12 \mathrm{~mm}$ mass in the inferotemporal quadrant that is encroaching on the macula. In the left eye (B), there are two smaller and slightly less elevated subretinal masses-a $1.5 \times 1.5 \mathrm{~mm}$ mass superior to the optic disc, and a $2.8 \times 3.0 \mathrm{~mm}$ mass along the inferotemporal arcade.

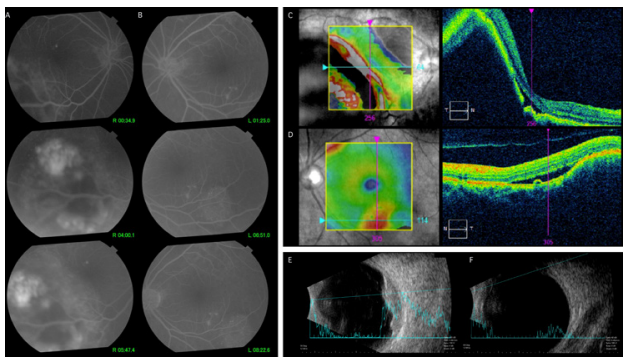

Figure 2 Multimodal imaging. Fluorescein angiogram of the right (A) and left (B) eyes. Optical coherence tomography of the right (C) and left (D) eyes. Ocular ultrasound, B-scan and A-scan, of the right (E) and left (F) eyes.

the choroid with A-scan exhibiting high amplitude spikes.

The patient was referred to an ocular oncologist. A chest CT scan was done which revealed a lung mass. Furthermore, abdominal CT scan and holoabdominal ultrasound revealed metastatic lesions in the liver, spleen and spine. The patient was eventually diagnosed to have stage IV small cell lung cancer. She was referred to an oncologist for further management.

The choroid is the most common ocular site for metastasis, primarily due to its abundant vascular supply. ${ }^{1}$ About $20 \%-40 \%$ of cases are bilateral and multifocal. There is no eye predilection. ${ }^{2}$ Choroidal metastasis may be asymptomatic or have non-specific symptoms such as photopsia, pain, eye redness, visual field defects and floaters. As shown in the case, vision loss occurs when there is involvement of the macular or peripapillary area. They usually present as yellow or white subretinal lesions associated with serous retinal detachments. The most common location is in the posterior pole, with $40 \%$ of cases reported to be in the macula. ${ }^{3}$

In the systemic evaluation of choroidal metastasis, work-up varies depending on location and status of primary tumour, as well as history of prior metastatic disease. The relative frequency of primary cancer sites varies by gender, with $68 \%$ of cases localised to the breast in women, and $40 \%$ of cases localised to the lung in men. In those without a prior history of malignancy, a primary site is usually detected in about $50 \%$, with $70 \%$ of these cases being lung cancer. ${ }^{34}$ Thus, breast imaging and chest CT scan are reasonable initial diagnostic tests to order as an initial investigation.

The case presented demonstrates how ophthalmologists can play a vital role in the diagnosis of 
malignancy. A routine eye examination revealed an underlying disease which significantly impacts the patient's life.

\section{Learning points}

The choroid is the most common ocular site affected by cancer metastasis.

- The most common primary tumour in patients with choroidal metastasis is breast cancer in women and lung cancer in men. Therefore, in patients with no known history of malignancy, breast imaging and chest CT are important in the initial evaluation.

- Ophthalmologists can play a vital role in catching the diagnosis of cancer in other parts of the body.

Contributors The authors, AJB, PG-Q, SJL and GJM, made substantial contributions to the conception or design of the work; or the acquisition, analysis or interpretation of data for the work, drafting the work or revising it critically for important intellectual content, and final approval of the version to be published. The authors agree to be accountable for all aspects of the work in ensuring that questions related to the accuracy or integrity of any part of the work are appropriately investigated and resolved.

Funding The authors have not declared a specific grant for this research from any funding agency in the public, commercial or not-for-profit sectors.

Competing interests None declared.

Patient consent for publication Obtained.

Provenance and peer review Not commissioned; externally peer reviewed.

ORCID iD

Albert John Bromeo http://orcid.org/0000-0001-7983-6369

\section{REFERENCES}

1 Arepalli S, Kaliki S, Shields CL. Choroidal metastases: origin, features, and therapy. Indian J Ophthalmol 2015;63:122.

2 Bloch RS, Gartner S. The incidence of ocular metastatic carcinoma. Arch Ophthalmol 1971;85:673-5.

3 Stephens RF, Shields JA. Diagnosis and management of cancer metastatic to the uvea: a study of 70 cases. Ophthalmology 1979;86:1336-49.

4 Shields CL, Shields JA, Gross NE, et al. Survey of 520 eyes with uveal metastases, Ophthalmology 1997;104:1265-76.

Copyright 2020 BMJ Publishing Group. All rights reserved. For permission to reuse any of this content visit

https://www.bmj.com/company/products-services/rights-and-licensing/permissions/

BMJ Case Report Fellows may re-use this article for personal use and teaching without any further permission.

Become a Fellow of BMJ Case Reports today and you can:

- Submit as many cases as you like

- Enjoy fast sympathetic peer review and rapid publication of accepted articles

- Access all the published articles

Re-use any of the published material for personal use and teaching without further permission

\section{Customer Service}

If you have any further queries about your subscription, please contact our customer services team on +44 (0) 2071111105 or via email at support@bmj.com.

Visit casereports.bmj.com for more articles like this and to become a Fellow 